\title{
Morpho-Taxonomic Studies on the Genus Spirogyra Link (Cholorophyta) Occuring in Fresh Water Bodies of Jammu, Jammu And Kashmir
}

\author{
Priyanka Chalotra ${ }^{1}$, Madhvi Gaind ${ }^{2}$ and V.K. Anand ${ }^{3}$ \\ ${ }^{1,2,3}$ Department of Botany, University of Jammu, Jammu
}

\begin{abstract}
Sixteen species of Spirogyra Link 1820 (Zygnemophyceae, Chlorophyceae) were collected during 2008 to 2010 from different freshwater habitats of three districts of Jaтmu province viz., Samba district, Jammu district and Udhampur district. They were taxonomically determined on the basis of vegetative structure and reproductive structure. Their reproduction was mostly studied during winters and spring seasons. Both lateral conjugation and scalar form conjugation were observed. The scalariform conjugation was most common type of conjugation method among species. S. calcarea, $S$ rectispire, $S$ submarina, S hollandiae and $S$ buchetii were taxonomically determined and have been described for first time in India and Jammu. Their reproduction was observed to occur mostly in winter and spring season. All sixteen species were found abundantly in both lentic and lotic water habitat.
\end{abstract}

Key words: Spirogyra, Vegetative Structure, Reproductive structure, Lateral conjugation, Scalariform conjugation, morpho-taxonomic, lentic and lotic water bodies.

\section{Introduction}

The occurrence of Zygnematales in India was reported by Martens (1869). Lateron, Danforth (1910)and Carter (1926) studied the periodicity and occurrence of Spirogyra in winter season from high altitude of Missouri, Assam and Sikkim. Randhawa (1940) recorded various filamentous green algae occurring in India and complied a monograph of Zygnema in 1959. Lateron, Kumar\& Singh (1984) reported new species of Spirogyra from Uttar Pardesh

In Jammu, prior work on Zynematales was done by Misra (1937), he worked on four new taxa and recorded the distributed of seventeen more taxa belonging to genus Spirogyra and Zygnema growing in waters of Jammu \& Kashmir. He also recorded the occurrence of five species of Spirogyra from fresh water of Jammu.

The study on distribution and morphology of Zygnematales was further proceeded by Kant (1974) he studied that Spirogyra formed 80\% of its population in Lakes of Srinagar. Goyal et al,(1984) and Anand (1988) reported the occurence of Spirogyra species in fresh water of Jammu.

Since then no much work had been done in the field of taxonomic studies of Spirogyra growing in Jammu waters. Keeping in view the paucity of the work done on morphology and taxonomic studies on Spirogyra, an extensive survey had been conducted in three districts of Jammu (Jammu,Samba and Udhampur) from 2008 to 2010. While surveying various local water bodies like pond, puddles, road side ditches,lakes, slow moving streams, rivers etc. sixteen species of Spirogyra were studied, of which five species i.e, $S$ calcarea, $S$ rectispire, $S$ submarina, $S$ hollandiae and $S$ buchetii were new to Indian taxonomy.

\section{Materials And Methods}

Collections were made from Samba, Udhampur and Jammu districts of Jammu province during the period of January 2008 to March 2010.The specimens were obtained by hand-picking from various freshwater habitats like fountain water, running water channels, stagnant ponds and road-side puddles. They were preserved in glass bottles containing $5 \%$ formalin and brought to the laboratory, where they were stained in iodine solution and examined in $10 \%$ glycerin mounts under light microscope. Their drawings were made with the help of camera lucida and was micro photographed. The material was taxonomically determined with the help of authentic literature (Randhawa, 1959; Transeau,1951; Chin-Chin,1982; Vidyavati, 1995; Kargupta and Jha ,2004; Taft,2009).

\section{Results}

Sixteen species of pond scum genus Spirogyra ( phylum Chlorophyta, class Chlorophyceae, order Zygnemetales, family Zygnemetaceae) have been identified. Their taxonomic enumeration is as follows: 


\section{Spirogyra Link 1820}

The genus Spirogyra was founded by Link in 1820 and is represented by large number of species, filaments are free floating and rarely attached.

Vegetative features: Cells are cylindrical, $0.5-30 \mu$ times as long as broad; chloroplast 1- $16 \mu$ spirally arranged; parietal ribbon-like bodies with numerous prominent pyrenoids; nucleus centrally situated in a protoplasmic strand.

Reproductive features: Reproduction by zygospores, parthenosore, aplanospores, akinetes or by fragmentation; conjugation scalariform or lateral; zygospores usually ellipsoid, rarely ovoid or lenticula; median wall pale yellow to chestnut brown in colour; either smooth or variously ornamented.

The following sixteen species were collected which may be distinguished as follows:

Key to the local species of genus Spirogyra

$1 \quad$ Reproduction by Zygospores.................................... 2

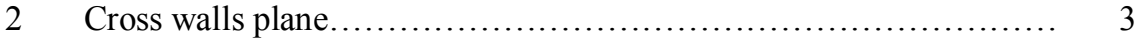

3 (a) Chloroplast one in each cell...................................... 4

3 (b) Chloroplast many in each cell ....................................... 5

4 (a) Gamentangia cylindric or enlarged................................ 6

6 (a) Vegetative cell $18-26 \mu$ broad ..................................... S. communis

6 (b) Vegetative cell $29-39 \mu$ broad ........................................ S. singularis

4 (b) Gamentangia swollen on both sides....................................... S. teodoresis

4 (c) Gametangia swollen on outer sides............................... 7

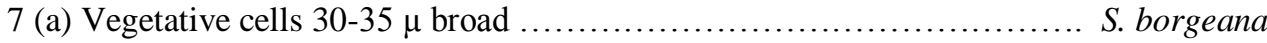

7 (b) Vegetative cells $37-42 \mu$ broad........................................ S. calcarea

5 (a) Zygospores laterally compressed....................................... 8

8 (a) Zygrospores ellipsoid............................................... S. crossoidea

8 (b) zygospores ovoid ................................................. S. rectispera

5 (b) Zygospores not laterally compressed ............................... 9

9 (a) Gametangia cylindric .............................................. 10

10 (a) Zygospores ellipsoid............................................ 11

11 (a) Veg.cell $21-32 \mu$ broad............................................. S. submarina

11 (b) Veg. cell 32-37 $\mu$ broad................................................... S. irregularis

11 (c) Veg. cell 36-41 $\mu$ broad .................................................. S. hollandiae

11 (d) Veg. cell 45-60 $\mu$ broad................................................. S. hyaline

11 (e) Veg. cell $55-60 \mu$ broad ................................................. pseudoneglata

11 (b) Zygospores cylindric ovoid............................................ S. neglecta

9 (b) Gamentangia swollen.............................................. 12

12 (a) Chloroplasts 3-4 in each cell ........................................... S. paradoxa

12 (b) Chloroplasts 2-3 in each cell........................................... S. dubia

12 c) Chloroplast 2 un each cell............................................. S. bucteii

1. Spriogyra communis ( Hassal) Kutzing.

( Randhawa, 1959. Zygnemataceae :247-293; Shameel,2006:p. 228; Pandoh, plate-VIII, Figs.40-43, 188-190)

Habitat and Habit: Lentic water conditions ; Free floating.

Vegetative feature: Vegetative cells $18-25 \mu$ x $40-75 \mu$; end wall plain ; chloroplast 1, making 1.5-4 turns ( Plate-I; Fig.1).

Reproductive features : Conjugation Scalariform; conjugation canal is formed by both gamentangia; fertile cell cylindrical ,rarely enlarged; Zygospores ellipsoid to ovoid, $19-25 \mu \times 42-78 \mu$; medium spore wall yellow and smooth ( Plate-I; Fig.2\&3).

\section{Geographical distribution:}

World : New Caledonia (U.S.A), North- east Pakistan, Poland

India: Gorakhpur ( U.P), Assam.

Jammu: Paddy fields of Seri, Bandhu Rakh stream (12-1-2008), Pond of Bagh-e- Bahu (8-2-2009), Seasonal pond of Sagoon (19-10-2008). 
Variations recoreded : This species was collected in winter seasons from the ditches, fields, ponds and puddles. This species is highly variable in cell dimensions, number of spiral turns of chloroplast, conjugation types differed from scalariform to lateral. Zygospore variations also differed

\section{Spriogyra singularis Nordstedt.}

( Randhawa, 1959, The Zygnemataceae : p.295,251; Hashaw etal.1985. 1005-1011; Wang etal, 1989: 367-373).

Habitat and Habit: Lentic water condition ; Free floating.

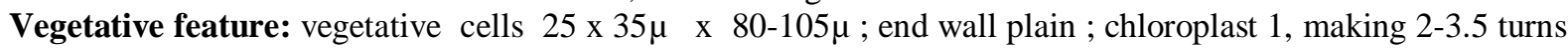
(Plate-I; Fig.4).

Reproductive features : Conjugation Scalariform; conjugation canal is formed by both gamentangia; fertile cell centirc ,rarely enlarged; Zygospores ellipsoid to oval, 23-32 $\times$ 45-65 $\mu$; medium spore wall yellowish brown and smooth (Plate-I; Fig5\&6).

\section{Geographical Distribution:}

World : China, South Africa, Brazil, Finland, New Zealand and U.S.A.

India: Bombay, Banaras, U.P, Punjab.

Jammu: Paddy fields of Raipur (13-8-2009), River Tawi (3-1-2009), Pond of Bagh- e- Bahu (8-2- 2009), ditches along the main stream, Jhajjar Kotli (27-11-2008).

Variation recorded: This species was collected in winter seasons from the ditches, fields, ponds and puddles and is rice field after monsoons. This species is highly variable in cell dimensions, number of spiral turns of chloroplast, turns varied from 3-7. Zygospore variations also differed

\section{Spriogyra teodoresci Transeau.}

(Transeau ,1934. Ohio. Jour. Sci. 34, p.420; Randhawa, 1959, The Zygnemataceae : p.296,255; Shameel,2006. p.246, fig IV,41 a-b).

Habitat and Habit: Lotic water condition ; Free floating.

Vegetative feature: Vegetative cells $20 \times 30 \mu \times 42-80 \mu$; chloroplast 1, making 1-2 turns (Plate-I; Fig-7).

Reproductive features : Conjugation Scalariform; conjugation canal is formed by both gamentangia; fertile cell slightly swollen on conjugation side ; Zygospores oval, 28-32 × 58-74 $\mu$; medium spore wall yellowish brown and smooth (Plate-I; Fig-8).

\section{Geographical distribution:}

World : Nanking, Peiping, China, Humania, U.S.A, Arizona, Pakistan

India: Not reported earlier.

Jammu: Slow moving stream Pragwal (2-3-2008), River Tawi tributray (14-12-2008), Lake Mansar (10-22009), ditches along the main stream at Jhajjar Kotli (4-1-2009).

Variation recorded: This species was collected in winter seasons from the ditches, fields, ponds and puddles. This species is highly variable in cell dimensions, number of spiral turns of chloroplast , turns varied from 1-6 . Zygospore variations also differed from $50-78 \mu$ to $52-80 \mu$.

\section{Spriogyra borgeana Transeau.}

(Transeau .1951. Ohio. Jour. Sci. 34, p.420; Randhawa, 1959, The Zygnemataceae; Shameel,2007. p.246, fig IV,41 a-b).

Habitat and Habit: Letic water condition; Free floating / Epiphytic on Potamegeton sp.

Vegetative feature: vegetative cells $35-48 \mu$ x $58-120 \mu$; chloroplast 1 , making 1-2 turns.

Reproductive features : Conjugation Scalariform; conjugation canal is formed by both gamentangia; fertile cell inflated on the outer side ; Zygospores ovoid to ellipsoid, 38-50 $\times 60-125 \mu$; medium spore wall brown; mesospore 2 layered and smooth (Plate-I; Fig-9). 


\section{Geographical distribution:}

World : Tibet, China, U.S.A, Pakistan

India: Not reported earlier.

Jammu: Pond in Botanical Garden, JU (7-01-2009), Lake Surinsar (4-1- 2008), ditches along the road side at Bishnah (15-3-2008).

Variation recorded: This species was collected in winter seasons from the ditches, fields, ponds and puddles. This species is highly variable in cell dimensions, number of spiral turns of chloroplast , turns varied from 1.5-5 .Zygospore varied in shape, oval to ellipsoid and yellow to brown, respectively.

\section{Spriogyra calearea Transeau.}

(Transeau ,1951. p.226; Randhawa, 1959, The Zygnemataceae, p 413, fig. 499).

Habitat and Habit: Letic water condition; Free floating / Epiphytic on Potamegeton sp.

Vegetative feature: Vegetative cells $38-40 \mu \quad$ x $60-75 \mu$; chloroplast 1, making 2-2.5 turns (Plate-I; Fig-10).

Reproductive features : Conjugation Scalariform; conjugation canal is formed by both gamentangia; receptive gamentangia inflated only on the outer side ; Zygospores ellipsoid, 40-45 $\times 65-78 \mu$; medium spore wall yellowish brown; smooth (Plate-I;Fig-11).

\section{Geographical distribution:}

World : U.S.A.

India: Not reported earlier.

Jammu: Ditches at Pragwal (17-10-2008),Slow moving stream at Bandhu Rakh (27-10- 2008), Agricultural f (15-3-2008).eilds at Tikri, Udhampur (12-10-2009), Permanent pond at Sagoon (21-10-2008).

Variation recorded: This species was collected in winter seasons from the ditches, fields, ponds and puddles. This species is highly variable in cell dimensions, number of spiral turns of chloroplast, turns varied from 2-3. Nature of reproductive cells show difference viz., fertile cells inflated on conjugating scale or inflated completely. Zygospores varied in dimension ,shape, colour and nature showed variability.

\section{Spriogyra crassoidea Transeau.}

(Transeau ,1951p.936 ; Randhawa, 1959, The Zygnemataceae, p.377 fig. 415; Khan and Usha.1971. Biology of Conjugales p.124-125; Shameel.2007. p.229.fig. 1,6).

Habitat and Habit: Letic water condition ; Free floating.

Vegetative feature: Vegetative cells $140-145 \mu$ x $180-320 \mu$; chloroplast 3, making 2-2.5 turns in each cell ( Plate-I; Fig- 12).

Reproductive features : Conjugation Scalariform; conjugation canal is formed by both gamentangia; fertile cells cylindric and slightly swollen on the inner side ; Zygospores ellipsoid, 125-140 $\mu \times 150-220 \mu$; medium spore wall brown; smooth (Plate-I; Fig-13).

\section{Geographical distribution:}

World : U.S.A, Brazil, India, Pakistan.

India: Punjab, Dehradun,U.P.

Jammu: Seasonal pond at village Gho Manasha (15-11-2008),Slow moving stream at Samba (5-2- 2008), Jhajjar Nallah (7-10-2008).Lake Mansar (12-1-2009), Seasonal pond at Sagoon (3-3-2008), Paddy Field at R.S.Pura (27-11-2009).

Variation recorded: This species was collected in winter seasons from the ditches, fields, ponds and puddles. This species is highly variable in cell dimensions, number of spiral turns of chloroplast , turns varied from 1-6. Nature of reproductive cells show difference viz., fertile cells inflated on conjugating scale or inflated completely. Zygospores varied in dimension, shape, colour and nature showed variability.

\section{Spriogyra rectispira Merriman .}

(Merriman 1922. Amer. Joun.Bot.9, p. 283 ; Randhawa, 1959, The Zygnemataceae, p.415 ; Kargupta,1998). 
Habitat and Habit: Letic water condition ; Free floating.

Vegetative feature: Vegetative cells $130-170 \mu$ x $80-280 \mu$; plain end walls; chloroplast 12-14, making 1-1.5 turns in each cell (Plate-I; Fig-14).

Reproductive features : Conjugation Scalariform; conjugation canal is formed by both gamentangia; fertile cells cylindric and slightly enlarged on the inner side ; Zygospores ellipsoid to ovoid, $155-145 \mu \times 100-120 \mu$; brown (Plate-I; Fig-15).

\section{Geographical distribution:}

World : U.S.A.

India: Not reported earlier.

Jammu: Man made pond at Bagh-e-Bahu (5-2-2008) .Athum pond at Jammu-Surinsar road (19-8-2008), Seasonal pond at Sagoon (4-1-2009), Paddy Field at Raipur (27-09-2008).

Variation recorded: This species was collected in winter seasons from the ditches, fields, ponds and puddles. This species is highly variable in cell dimensions, chloroplast number varied from 2-3, turns varied in number. Zygospores varied in dimension, shape, colour and nature showed variability.

\section{Spriogyra submarina Collins .}

(Transeau.1951. Ohio.Journal. Sci. p.25 ; Randhawa, 1959, The Zygnematace, p.415 ; Hoshaw.1968. p.65 , figs. 34-35; Wang. 1989. P.368; Dias.2006. p.400 ; Shameel.2007. p.244. fig.IV,38a ).

Habitat and Habit: Letic water condition ; Free floating.

Vegetative feature: Vegetative cells $20-35 \mu$ x $68-155 \mu$; plain end walls; chloroplast 3, making 2-3 turns in each cell (Plate-I; Fig-16) .

Reproductive features : Conjugation Scalariform; conjugation canal is formed by both gamentangia; fertile cells cylindric and slightly enlarged on the inner side ; Zygospores ellipsoid to ovoid, 25-37 $\mu \times 55-125 \mu$; brown (Plate-I;Fig-17).

\section{Geographical distribution:}

World : U.S.A, China, Brazil, Pakistan, Bermuda

India: Not reported earlier .

Jammu: Agriculture field Bishnah (12-8-2008), Paddy Field at R S Pura (07-09-2008).

Variation recorded: This species was collected in winter seasons from the ditches, fields, ponds and puddles. This species is highly variable in cell dimensions, chloroplast number varied from 2-3, turns varied in number. Zygospores varied in dimension, shape, colour and nature showed variability

\section{Spriogyra irregularis Nagelli .}

(Nagelli.1849. In Kutzing Species Algarum. p. 440 ; Randhawa, 1959, The Zygnematace, p.316:90 ; Shameel.2007. p.235. fig.II,19a-b; Naskar et al.2009.p.189.fig. 6 ).

Habitat and Habit: Lotic water condition ; Free floating.

Vegetative feature: Vegetative cells $35-38 \mu \quad$ x $80-210 \mu$; plain end walls; chloroplast 3-4, making $0.5-1$ turns in each cell (Plate-II; Fig-18).

Reproductive features : Conjugation Scalariform; conjugation canal is formed by both gamentangia; fertile cells cylindric and slightly enlarged on the inner side ; Zygospores ellipsoid to ovoid, $32-35 \mu \times 45-85 \mu$; yellowish brown (Plate-II;Fig-19).

\section{Geographical distribution:}

World : Western and Central U.S.A, Pakistan.

India: Sunderbands.

Jammu: Ditches along the road side Bishnah (15-3-2008), Lake Surisar (6-12-2008), Permanent pond in Botanical Gardern JU (17-1-2008). 
Variation recorded: This species was collected in winter seasons from the ditches, fields, ponds and puddles. This species is highly variable in cell dimensions, chloroplast number varied, turns varied in number from 1.55. Zygospores varied in dimension, shape, colour and nature showed variability.

10. Spriogyra hollandiae Taft .

(Taft.1947. Ohio Jour.Sci. 47, p.173, fig. 9-11 ; Randhawa, 1959, The Zygnematace, p.407:486).

Habitat and Habit: Lotic water condition ; Free floating.

Vegetative feature: Vegetative cells $32-35 \mu$ x $68-120 \mu$; plain end walls; chloroplast 2, making 2-3 turns in each cell (Plate-II; Fig-20).

Reproductive features : Conjugation Scalariform; conjugation canal is formed by both gamentangia; fertile cells cylindric or slightly enlarged on the inner side ; Zygospores ellipsoid, 34-36 $\mu \times 70-75 \mu$; yellow to brown at maturity (Plate-II; Fig-21).

\section{Geographical distribution:}

World : Dutch New Guinea.

India: Not reported earlier

Jammu: Lake Mansar (15-08-2009), Permanent pond in Bagh-e-Bahu (7-1-2008).

Variation recorded: This species was collected in winter seasons from the ditches, fields, ponds and puddles. This species is highly variable in cell dimensions, chloroplast number varied from 2-4, turns varied in number from 1-2.5. Zygospores varied in dimension, shape, colour and nature showed variability.

\section{Spriogyra hyaline Cleve .}

(Cleve. 1868. Nova Acta Reg. Soc. Sci. Upsali. Ser.3,6. p .17, pl.3, fig. 1-6; Randhawa, 1959, The Zygnematace, p.318:294 (a-c); Shameel,2007. p.234, fig. II, 17 a-b; Dias.2006. Hoshaw.1968. Naskar.2009.p.188,pl.2, fig. IV).

Habitat and Habit: Letic water condition ; Free floating.

Vegetative feature: Vegetative cells $45-50 \mu \quad \mathrm{x} 150-200 \mu$; plain end walls; chloroplast 4, making 2-2.5 turns in each cell (Plate-II; Fig-22).

Reproductive features : Conjugation Scalariform; conjugation canal is formed by both gamentangia; fertile cells cylindric; Zygospores ellipsoid , 48-52 $\mu \times 155-175 \mu$; brown (Plate-II; Fig-23).

\section{Geographical distribution:}

World : China, Sweden, U.S.A.

India: Widely distributed

Jammu: Slow- moving stream at Bandhu Rakh (15-08-2009), Permanent pond in Bagh-e-Bahu (7-1-2008), Agricultural field at Tikri (3-4-2008).I

Variation recorded: This species was collected in winter seasons from the ditches, fields, ponds and puddles. This species is highly variable in cell dimensions, chloroplast number varied from 2-4, turns varied . Zygospores varied in dimension, shape, colour and nature showed variability.

12. Spriogyra pseudoneglecta Czurda .

(Czurda.1932. Susswasserflora Mitteleuropa. 9, p. 194 ; Randhawa, 1959, The Zygnematace, p.390:296 a-b).

Habitat and Habit: Letic water condition ; Free floating.

Vegetative feature: Vegetative cells $50-60 \mu \times 132-150 \mu$; plain end walls; chloroplast 3, making 1.5-2 turns in each cell (Plate-II; Fig-24).

Reproductive features : Conjugation Scalariform; conjugation canal is formed by both gamentangia; fertile cells cylindrical or swollen slightly ; Zygospores ellipsoid , 60-65 $\mu \times 98-120 \mu$; median spore wall reddish brown, mesospore 3 layered, smooth (Plate-II; Fig-25). 


\section{Geographical distribution:}

World : Moravia.

India: M.P

Jammu: Slow- moving stream at Bandhu Rakh (15-08-2009), Permanent pond in Sagoon (7-1-2008), Agricultural field at Tikri (3-4-2008), Ditches of Pragwal (17-10-2008).

Variation recorded: This species was collected in winter seasons from the ditches, fields, ponds and puddles. This species is highly variable in cell dimensions, chloroplast number varied, turns varied from 1-2, Nature of reproductive cell show difference viz., fertile cells inflated on conjugating scale or inflated completely . Zygospores varied in dimension, shape, colour and nature showed variability.

\section{Spriogyra neglecta (Hassall) Kutzing .}

(Kutzin.1849. Species Algarum, p.441; Randhawa, 1959, The Zygnematace, p.324:308; Dias.2006.p.420; Naskar et al,.2009.p. 188, pl.1).

Habitat and Habit: Letic/lotic water condition ; Free floating.

Vegetative feature: Vegetative cells $52-60 \mu \times 162-185 \mu$; plain end walls; chloroplast 4, making 2-2.5 turns in each cell (Plate-II; Fig-26).

Reproductive features : Conjugation Scalariform; conjugation canal is formed by both gamentangia; fertile cells swollen slightly on the conjugating side ; Zygospores oval, 54-62 $\mu \times 162-187 \mu$ brown, mesospore, smooth (Plate-II; Fig-27).

\section{Geographical distribution:}

World : Brazil, China, Germany, Finland, U.S.A, Siam,South Africa, Macedonia, Java.

India: M.P, U.P.Calcutta, Punjab.

Jammu: Slow- moving stream near Surinsar (12-10-2009), ditches along the main stream Jhajjar Kolti (17-102008), Agricultural field at Tikri (6-11-2008), Ditches along the road side at Samba (4-1-2008).

Variation recorded: This species was collected in winter seasons from the ditches, fields, ponds and puddles. This species is highly variable in cell dimensions, chloroplast number varied from 3-4. Zygospores varied in dimension, shape, colour and nature showed variability.

\section{Spriogyra paradoxa Rao .}

(Rao.1937. J. Indian Bot. Soc.,16.p.281.fig.5; Randhawa, 1959, The Zygnematace, p.326:313).

Habitat and Habit: Letic water condition ; Free floating.

Vegetative feature: Vegetative cells $80-92 \mu \times 70-85 \mu$; plain end walls; chloroplast 3-4, making 1-2 turns in each cell (Plate-II; Fig-28).

Reproductive features : Conjugation Scalariform; conjugation canal is formed by both gamentangia; fertile

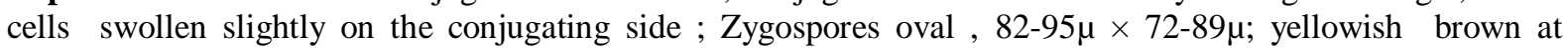
maturity; median spore wall 2 layered, smooth (Plate-II; Fig-29).

\section{Geographical distribution:}

India: U.P,Bihar.

Jammu: Slow- moving stream near Surinsar (12-10-2009), ditches along the main stream Jhajjar Kolti (17-102008), Agricultural field at Tikri (6-11-2008), Ditches along the road side at Samba (4-1-2008).

Variation recorded: This species was collected in winter seasons from the ditches, fields, ponds and puddles. This species is highly variable in cell dimensions, number of chloroplast turns varied from 1-3.5. Shape of zygospores showed varation i.e, spherical to oval. Zygospores varied in dimension, shape, colour and nature showed variability. Layers of zygospores ranged from2-3. 
15. Spriogyra dubia (Kutzing) Czurda .

(Czurda.1932. Sussawasserflora Mitteluropa 9, p. 188; Danforth.1910.p.51; Randhawa, 1959, The Zygnematace, p.329:317; Rattan.1968.Biology of Conjugles. P.109; Kargupta.1998. p.237; Dias.2006.p.399; Kim et al,.2006. p.297; Shameel.2007. p.230.fig.I.9 a-b).

Habitat and Habit: Letic water condition ; Free floating.

Vegetative feature: Vegetative cells $52-58 \mu \times$ x 90-110 $\mu$; plain end walls; chloroplast 2, making 2-3 turns in each cell (Plate-II; Fig-30).

Reproductive features : Conjugation Scalariform; conjugation canal is formed by both gamentangia; fertile cells swollen slightly on the conjugating side ; Zygospores oval , $50-55 \mu \times 88-100 \mu$; mesospores thick, smooth brown (Plate-II; Fig-31).

\section{Geographical distribution:}

World: Africa, Bulgaria, Egypt, North America

India: Jabbalpore,M.P, U.P.

Jammu: Slow- Fountain -cum-pond at Bikram Chowk (25-5-2009), ditches along the main stream Jhajjar Kolti (19-10-2008), A seasonal pond at Sagoon (7-3-2008), Ditches along the road side at Pragwal (17-2-2009).

Variation recorded: This species was collected in winter seasons from the ditches, fields, ponds and puddles. This species is highly variable in cell dimensions, number of chloroplast varied from 2-4, number of chloroplast turns varied from 2-4. Reproductive cell show slight variation in nature. Zygospores wall ranges from 2-3 and also showed variation in colour and ornamentation.

\section{Spriogyra buchetii Petit.}

(Petit.1913. Bull. Soc.Bot.De France. 60, pp 40-43; Randhawa, 1959, The Zygnematace, p.416; Rattan.1968. Biology of Conjugles. P.128).

Habitat and Habit: Letic water condition ; Free floating.

Vegetative feature: Vegetative cells $45-48 \mu \times 120-140 \mu$; plain end walls; chloroplast 2, making 2-3 turns in each cell (Plate-II; Fig-32)..

Reproductive features : Conjugation Scalariform; conjugation canal is formed by both gamentangia; fertile cells inflated from outer side ; Zygospores ellipsoid to oval, $47-50 \mu \times 125-150 \mu$;median spore wall yellow, mesopores 2 layered, smooth (Plate-II; Fig-133).

\section{Geographical distribution:}

World: China, Moracco, U.S.A.

India: Not reported earlier

Jammu: Slow- Fountain -cum-pond at Bikram Chowk (25-5-2009), Agriculture field Gajansoo (12-1-2008).

Variation recorded: This species was collected in winter seasons from the ditches, fields, ponds and puddles. This species is highly variable in cell dimensions, number of chloroplast varied, number of chloroplast turns varied. Reproductive cell varies viz, shortened oval inflated to $50-52 \mu$. Zygospores dimension and colour also showed difference.

\section{References:}

[1]. Anand, V.K.(1988).Limnology of freshwater Algae of the Gadi garh stream, Jammu. Journal current bioscience. 5 (1): 11 -16

[2]. Chin-Chi ,J.(1982). Notes on the Zygnemataceae of China. J. Oceanology and Limnology 1(1).

[3]. Cleve. 1868. Nova Acta Reg. Soc. Sci. Upsali. Ser.3,6. p.17, pl.3, fig. 1-6

[4]. Czurda, V. 1932. Zygnemales. In: Die Süßwasserflora Mitteleuropas. (Ed.): A. Pascher. Vol. 9,a Gustav Fischer Verlag, Jena, 230 pp.

[5]. Danforth, .C.H.(1910). Periodicity in Spirogyra with special reference to the work of Benecke. Missouri Botanical Garden Annual Report : 49-59.

[6]. Dias, I.C.A and Bicudo. C.E.de M.(2006). Studies on Brazilian Zygnemaceae an overview. APC Publications New Delhi .1:141154.

[7]. Goyal, S.K, Sharma, B.M and Gupta, R.S.(1984). Algal flora of rice fields soils of Jammu and Kashmir state. Phykos. 23 (1\&2): 5964.

[8]. Hoshaw, R.W., Wang,, J.C.,McCourt, R.M. and Hull, H.M.(1985). Ploidal changes in clonal cultures of Spirogyra communis and implication for species defination. American Journal of Botany 72(7):1005-1011.

[9]. Kant, S.(1974). On some species of Zygnema from Jammu. Current Science. 43(16):523-524. 
[10]. Kargupta, A.N. and Jha,R.N.(2004). Algal flora of Bihar (Zygnemataceae). Bishen Singh Mahendra Pal Singh, Dehra Dun ,India

[11]. Kargupta, A.N.(1998). Conjugation in Zygnemataceae. Advances in Phycology:119-135.

[12]. Khan and Usha.1971. Biology of Conjugales p.124-125

[13]. Kim,J.H., Kim, Y.H., Cho, G.Y. and Boo, S.M.(2006). Plastid rbcl Gene Phylogeny of Genus Spirogyra (Chlorophyta, Zygnematacea) from Korea. Korean Journal of Genetics. 28(3):295-303.

[14]. Kumar, H.D. and Singh, H.N.(1984). A text book on Algae. Third Ed: 242-243. East- West Press, New Delhi.

[15]. Kutzin.1849. Species Algarum, p.441

[16]. Merriman 1922. Amer. Joun.Bot.9, p. 283

[17]. Nagelli.1849. In Kutzing Species Algarum. p. 440

[18]. Pandoh,A.1998. Algal Flora of Paddy Fields of Jammu. Ph.d Thesis. University of Jammu, Jammu.

[19]. Petit.1913. Bull. Soc.Bot.De France. 60, pp 40-43

[20]. Raandhawa, M.S.1940. Some peculiarities in conjugation in new Himalayan species of Zygnema .129.

[21]. Randhawa, M.S. 1959. Zygnemaceae. ICAR, New Delhi, 478 pp.

[22]. Rao, C.B. 1937. The Zygnemoideae of the United Provinces, India-I. J. Ind. Bot. Soc., 16: 269-288.

[23]. Rattan.1968.Biology of Conjugles. P.109

[24]. Shameel, M. 2006. New concept of the class Zygnemophyceae (Chlorophyta). Int. J. Phycol. Phycochem., 2: 103-104

[25]. Taft, C.E.2009. Some Oedogoniacea and Zygnemataceae from Texas and Louisiane. Transction of American Microscopial Society. 65 (1): $18-26$

[26]. Transeau, E.N. 1951. The Zygnemataceae.( Ohio. State Univ. Press, Columbus, 327 pp).

[27]. Vidyavati.(1995). Biology of Conjugales. Pritwell. Jaipur.

[28]. Wang, J.C., Hoshaw, R.W and McCourt, R.M.(1989). Diversity of Spirogyra (Chlorophyta) filament types on an altitudnal gradient. Br. Phycology Journal. 24:367-373.

\section{Plate I}

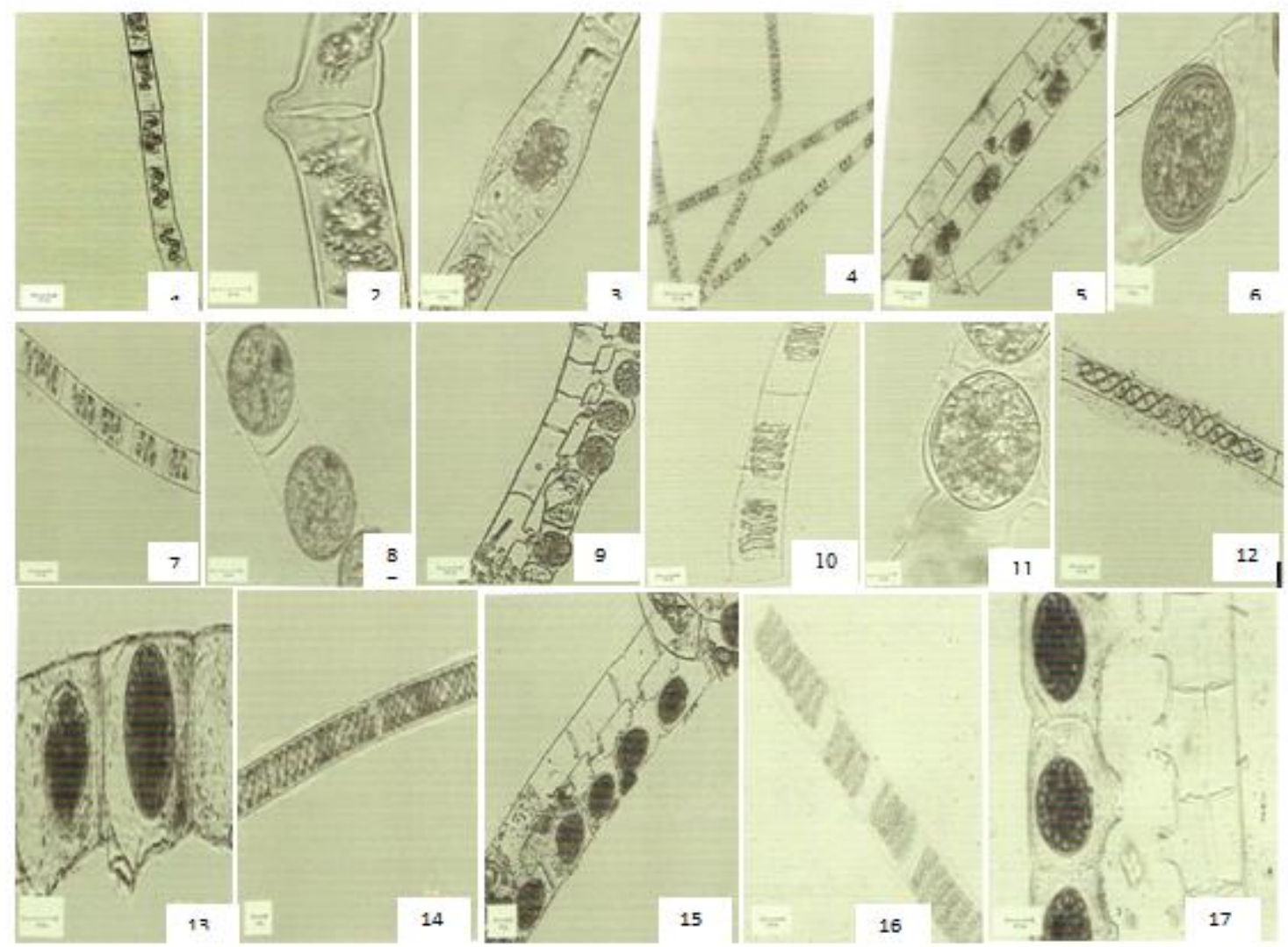

Fig.1- $S$ communis vegetative filament; Fig.2- $S$ communis Lateral conjugation; Fig.3-Alpanospore of $S$ communis; Fig.4- $S$ singularis Vegetative filament; Fig.5- $S$ singularis Scalariform conjugation; Fig.6Zygospore of $S$ singularis; Fig.7-S teodoresei Vegetative filament; Fig.8-Zygospore of $S$ teodoresei; Fig.9- $S$ borgeana Scalariform conjugation; Fig.10- $S$ calcarea Vegetative filament; Fig.11- $S$ calcarea Zygospore; Fig.12-S crassoidea Vegetative filament; Fig.13-S crassoidea Receptive gametangia; Fig.14- $S$ rectispira vegetative filament; Fig.15- $S$ rectispira scalariform conjugation; Fig.16- $S$ submarina vegetative filament; Fig.17- S submarina Scalariform conjugation. 

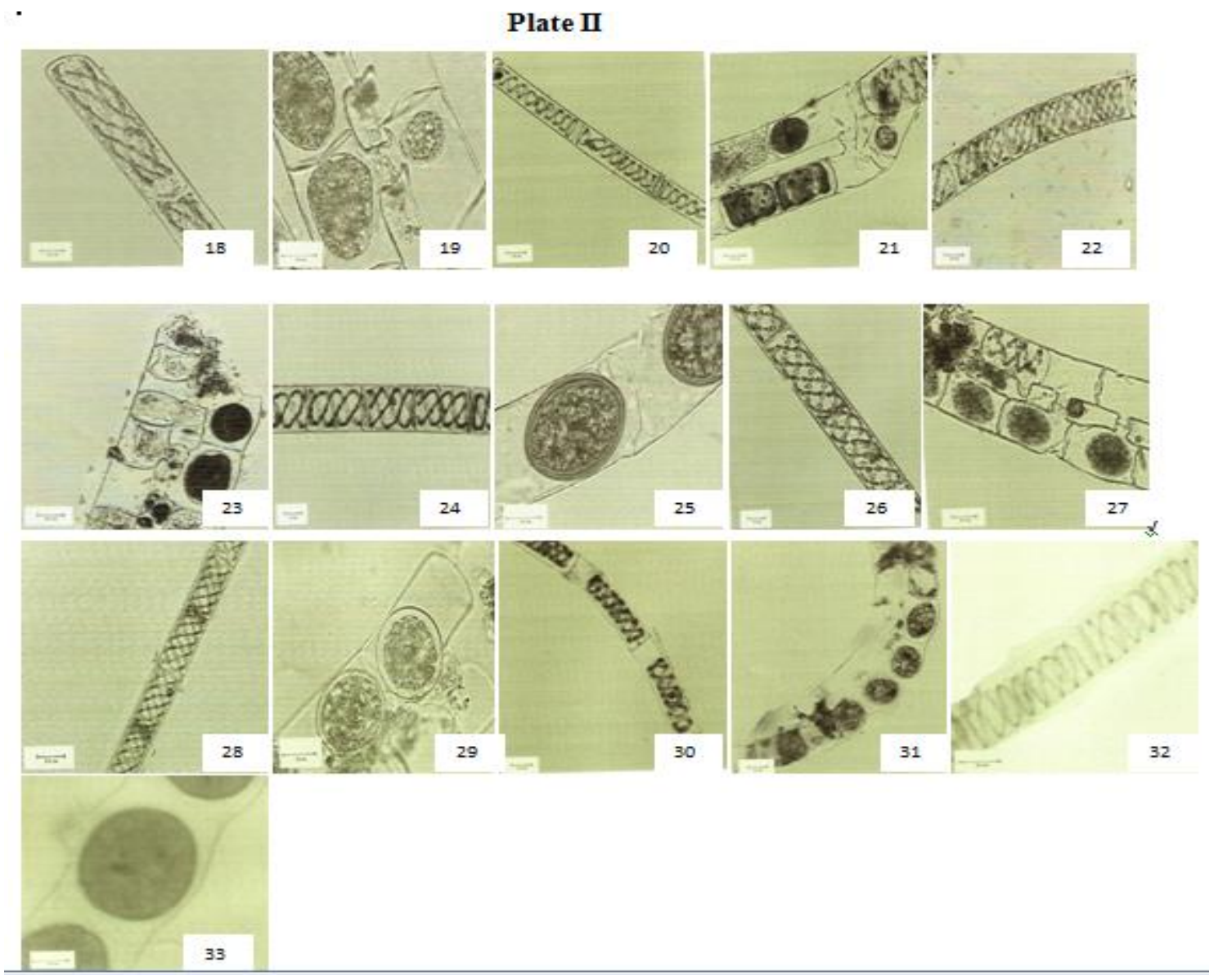

Fig.18- $S$ irregularis vegetative filament; Fig.19- $S$ irregularis scalariform conjugation and Zygospore formation; Fig.20- $S$ hollandiae Vegetative filament; Fig.21- $S$ hollandiae Scalariform conjugation; Fig.22- $S$ hyalina Vegetative filament; Fig.23-S hyaline Scalariform conjugation; Fig.24- $S$ pseudoneglecta vegetative filament; Fig.25- S pseudoneglecta Mature zygospore; Fig.26- S neglecta vegetative filament; Fig. 27-S neglecta Scalariform conjugation; Fig.28-S paradoxa vegetative filament; Fig.29- S paradoxa Mature zygospore; Fig.30- $S$ dubia vegetative filament; Fig.31- S dubia Scalariform conjugation; Fig.32-S buchetii vegetative filament; Fig.33- S buchetii Zygospores. 